Article

\title{
Corrosion Protection of Al/Au/ZnO Anode for Hybrid Cell Application
}

\section{Gymama Slaughter * and Brian Stevens}

Bioelectronics Laboratory, Department of Computer Science and Electrical Engineering, University of Maryland Baltimore County, Baltimore, MD 21250, USA;

E-Mail: bstevens1@umbc.edu

* Author to whom correspondence should be addressed; E-Mail: gslaught@umbc.edu; Tel.: +1-410-455-8483; Fax: +1-410-455-3969.

Academic Editor: Bruno Scrosati

Received: 18 September 2015 / Accepted: 11 November 2015 / Published: 16 November 2015

Abstract: Effective protection of power sources from corrosion is critical in the development of abiotic fuel cells, biofuel cells, hybrid cells and biobateries for implantable bioelectronics. Corrosion of these bioelectronic devices result in device inability to generate bioelectricity. In this paper $\mathrm{Al} / \mathrm{Au} / \mathrm{ZnO}$ was considered as a possible anodic substrate for the development of a hybrid cell. The protective abilities of corrosive resistant aluminum hydroxide and zinc phosphite composite films formed on the surface of $\mathrm{Al} / \mathrm{Au} / \mathrm{ZnO}$ anode in various electrolyte environments were examined by electrochemical methods. The presence of phosphate buffer and physiological saline $(\mathrm{NaCl})$ buffer allows for the formation of aluminum hyrdroxide and zinc phosphite composite films on the surface of the $\mathrm{Al} / \mathrm{Au} / \mathrm{ZnO}$ anode that prevent further corrosion of the anode. The highly protective films formed on the $\mathrm{Al} / \mathrm{Au} / \mathrm{ZnO}$ anode during energy harvesting in a physiological saline environment resulted in $98.5 \%$ corrosion protective efficiency, thereby demonstrating that the formation of aluminum hydroxide and zinc phosphite composite films are effective in the prevention of anode corrosion during energy harvesting. A cell assembly consisting of the $\mathrm{Al} / \mathrm{Au} / \mathrm{ZnO}$ anode and platinum cathode resulted in an open circuit voltage of $1.03 \mathrm{~V}$. A maximum power density of $955.3 \mu \mathrm{W} / \mathrm{cm}^{2}$ in physiological saline buffer at a cell voltage and current density of $345 \mathrm{mV}$ and $2.89 \mathrm{~mA} / \mathrm{cm}^{2}$, respectively.

Keywords: corrosion protection; aluminum activation; oxides; nanostructures; sol-gel growth 


\section{Introductions}

Approximately $8 \%$ to $10 \%$ of Americans and $5 \%$ to $6 \%$ of the industrialized world's population have implantable bioelectronic devices [1]. The bioelectronic device implant and biocompatible material market in the United States are 12 and 11 billion dollar industries, respectively. These markets are increasing about $9 \%$ every year [2]. Implantable bioelectronics are used for treating diseases, birth defects and the aging population for the overall improvement in the quality of life of the inflicted individuals. This further leads to the reduction of health care costs of the overall population. These implantable bioelectronics range from organ and neuro-stimulators [3] and regeneration devices [4], pacemakers [5-7], drug delivery devices [8,9], sensors [10-12], and activation circuits that monitor orthopedic implants [13]. These implantable devices could someday be powered by implantable power sources. Most implantable bioelectronics require an internal source of power, which can be accomplished with the help of implantable power sources such as, biobatteries, hybrid cells, biofuel cells and abiotic fuel cells that use abiotic anode or enzymatic anode to catalyze natural occurring fuel inside the body. The $\mathrm{Al} / \mathrm{Au} / \mathrm{ZnO}$ nanostructured anodes have been employed to selectively catalyze glucose in the presence of oxygen in a glucose/ $\mathrm{O}_{2}$ fuel cell [14], as well as to generate bioelectricity by activating the $\mathrm{Al}$ underneath the $\mathrm{ZnO}$ as anodic material in a hybrid cell supplied with phosphate rich electrolyte [15] in the realization of implantable power sources.

In addition, implantable bioelectronic power sources use biomaterials to enhance the biocompatibility, longevity and corrosion protection of the implantable devices from the harsh environments of the body [16-18] without adverse side effects. The body is an extremely corrosive environment because of cations such as $\mathrm{Na}^{+}, \mathrm{K}^{+}, \mathrm{Ca}^{+}, \mathrm{Mg}^{+}$, anions such as chloride, bicarbonate, phosphate, and large amounts of dissolved oxygen found throughout the body [19-21]. These molecules upset the chemical balance on the surface of implanted materials that lead to the consumption of these materials via anodic or cathodic reactions through galvanic corrosion. This corrosion occurs mostly with metallic substrates used to provide structural rigidity and electrical conduction path in bioelectronic devices. The main cause of corrosion comes from oxidation and reduction reactions between metallic materials and biological fluids. In particular, $\mathrm{Cl}^{-}$ions and dissolved oxygen are the major factors in corrosion within the body because of their ability to deteriorate metal substrates. Moreover, implant corrosion can cause serious side effects because of the release of metal anions into the surrounding environments and blood stream. These ions harm the body by either direct toxic effects or local hypersensitivity reactions. Elements such as nickel, cobalt, and chromium as well as their compounds are known allergens [22,23]. Aluminum [24], copper and zinc [25] ions have been associated with Alzheimer's disease as well as other neurological disorders such as epilepsy. These effects of corrosion from implantable devices has heightened the need for corrosion prevention, especially when harvesting energy from within the body.

Traditionally, corrosion protection is achieved through phosphating using acidic phosphate baths that use nitrates and nitrites. This process has been found to be harmful to the environment [26], whereas anodic acceleration has been employed to produce biocompatible zinc phosphate and zinc phosphate's hydrated tertiary form, hopeite [27], in physiological conditions using basic neutral $\mathrm{pH}$ and buffer solutions. This allows phosphating to occur utilizing biocompatible materials [28-33] which not only prevent corrosion but could also generate electricity for biomedical applications. This process can be 
defined as a biomimetic coating treatment because the process mimics an in vivo process for the application of phosphate coatings on an anodic substrate. These biomimetic coatings have also been demonstrated for magnesium substrates by several research groups [34,35], but biomimetic zinc phosphite research has yet to be performed. Here, we explore the application of corrosion prevention for the protection of bioelectronic power sources. Without corrosion protection, bioelectronics devices cease to produce reliable power and can leach harmful metal ions into the body.

In this paper, we take advantage of an economical biomimetic phosphating approach with the ability to form zinc phosphite film in physiological conditions, while generating bioelectricity. The $\mathrm{Al} / \mathrm{Au} / \mathrm{ZnO}$ anode is used for anodic electrochemical treatment in a phosphate rich bath to create corrosion resistive films as well as to produce power for bioelectronic applications. Our approach utilizes a low-cost and "green" alternative method that demonstrates effective corrosion resistance of the anodic substrate. We demonstrate that $\mathrm{Al} / \mathrm{Au} / \mathrm{ZnO}$ anode can be protected in a saline rich solution by the formation of zinc phosphites under physiological conditions rather than using other acidic, high energy and expensive techniques. This technique could be implemented in the body as described by Heller et al. [30] as corrosion protection for a bioelectronics power supply for implanted electrical devices.

\section{Material and Methods}

Aluminum foil $(99.9999 \%, 250 \mathrm{~mm}$ thick) substrates were cleaned with acetone, isopropanol and deionized water in preparation and fabrication of the $\mathrm{Al} / \mathrm{Au} / \mathrm{ZnO}$ anode using a sol-gel processes [34-36]. Magnetron sputtering was used to sputter $40 \mathrm{~nm}$ of gold to coat the surface of aluminum substrates. The aluminum (Al) surface activation was achieve via $\mathrm{ZnO}$ nanocrystal before zinc phosphating in an $\mathrm{Al} /$ phosphate hybrid cell. $\mathrm{ZnO}$ precursors were prepared by using $0.4 \mathrm{M}$ zinc chloride (99.99\%) and isopropanol. The solution was mixed at $75{ }^{\circ} \mathrm{C}$ and equimolar triethenamine was added to stabilize the precursor solution to yield a $0.1 \mathrm{M}$ homogenous $\mathrm{ZnO}$ nanosol, which was aged at $85{ }^{\circ} \mathrm{C}$. The $\mathrm{ZnO}$ seed layers were deposited on the $\mathrm{Al} / \mathrm{Au}$ substrate using a dip coating method upon aging of the solution. The solvent was allowed to naturally evaporate followed by annealing at $150{ }^{\circ} \mathrm{C}$ for 1 hour. The dip coat method was repeated multiple times to create a uniform seed layer and finally dried at $30{ }^{\circ} \mathrm{C}$ in a convection oven for 12 hours [14,15,36].

All current-voltage and power curves were obtained by acquiring the current and voltage through and across a variable load. Device durability tests of the assembled cell were performed with the $\mathrm{Al} / \mathrm{Au} / \mathrm{ZnO}$ anode and a Pt cathode at a load of $3 \mathrm{k} \Omega$, since the maximum power for the hybrid cells were obtained at a load of $3 \mathrm{k} \Omega$, while monitoring the corrosion protection of the anode in various electrolyte environments. Every two days, the spent electrolyte (saline: $2.7 \mathrm{mM} \mathrm{KCl}$ and $137 \mathrm{mM} \mathrm{NaCl}$ or physiological saline: $20 \mathrm{mM}$ phosphate, $2.7 \mathrm{mM} \mathrm{KCl}$ and $137 \mathrm{mM} \mathrm{NaCl}, \mathrm{pH} 7.4$ ) was exchange of for a fresh electrolyte.

The formation of the corrosion protection layer (aluminum hydroxide and phosphite) on the $\mathrm{Al} / \mathrm{Au} / \mathrm{ZnO}$ anode was achieved by discharging the anode in physiological saline using a two-electrode cell configuration (platinum served as the cathode) across $3 \mathrm{k} \Omega$ resistor for $10-15 \mathrm{~min}$. Polarization curves were obtained for both bare $\mathrm{Al}, \mathrm{Al} / \mathrm{Au}$, untreated $\mathrm{Al} / \mathrm{Au} / \mathrm{ZnO}$, saline treated $\mathrm{Al} / \mathrm{Au} / \mathrm{ZnO}$ and aluminum hydroxide and phosphite coated $\mathrm{Al} / \mathrm{Au} / \mathrm{ZnO}$ anodes in $20 \mathrm{mM}$ phosphate buffer solution at room temperature using a three-electrode cell configuration. $\mathrm{Ag} / \mathrm{AgCl}$ and platinum electrode were used 
as the reference and counter electrodes, respectively. The protective abilities of corrosive resistant films formed on the surface of $\mathrm{Al} / \mathrm{Au} / \mathrm{ZnO}$ anode in different electrolyte environments were examined using electrochemical impedance spectroscopy. An a.c. potential of $10 \mathrm{mV}$-p was applied over the frequency range of $100 \mathrm{kHz}$ to $10 \mathrm{mHz}$.

\section{Results and Discussion}

The as-prepared $\mathrm{Al} / \mathrm{Au} / \mathrm{ZnO}$ anodes $(1 \mathrm{~cm} \times 0.5 \mathrm{~cm})$ and platinum cathodes $(\phi=500 \mu \mathrm{m})$ were assembled to realize a hybrid cell operating in physiological saline buffer $(\mathrm{pH} 7.4)$ saturated with $\mathrm{O}_{2}$. In the hybrid cell, the nanostructured $\mathrm{ZnO}$ plugged in on the anodic electrode surface (Figure 1A) results in the $\mathrm{Al} / \mathrm{Al}^{3+}$ oxidation via pitting mechanism originating from the defect site to overcome the thin oxide film on the Al substrate in physiological saline. The oxidation of the byproduct of the anodic reaction, hydrogen, results in the release of electrons that recombines with the $\mathrm{H}_{2} \mathrm{PO}_{4}{ }^{-}$ions on the surface of the platinum cathode to reduce it to $\mathrm{HPO}_{3}{ }^{2-}$ ions. These ions then react with $\mathrm{Zn}^{2+}$ release from $\mathrm{ZnO}$ nanocrystals and the adsorption and precipitation of $\mathrm{HPO}_{3}{ }^{2-}$ results in the formation of $\mathrm{Al}(\mathrm{OH})_{3}$ and $\mathrm{ZnHPO}_{3}$ composite on the anode (Figure 1B). The current-voltage and power characteristics were acquired immediately upon assembling the hybrid cell and are shown in Figure 2. This cell achieved a 6-fold increase in performance compared to the previously reported $\mathrm{Al} / \mathrm{Au} / \mathrm{ZnO}$ anode in abiotic fuel cell application [15]. The maximum power density in physiological saline buffer was $955.3 \mu \mathrm{W} / \mathrm{cm}^{2}$ at a cell voltage of $345 \mathrm{mV}$ with approximately the same open circuit voltage value. This enhancement in performance can be attributed to the increased $\mathrm{ZnO}$ nanoseed layer deposited on the $\mathrm{Al} / \mathrm{Au}$ substrate. The highest maximum power density reported to date is achieved using $\mathrm{Al} / \mathrm{Au} / \mathrm{ZnO}$ anode described here when compared to enzymatic and abiotic fuel cells and biobatteries that use biological fluids as an electrolyte. Briefly, enzymatic fuel cells have the potential to exhibit long life spans but lack in high electrical characteristics when compared with lithium ion cells [37,38]. Although, enzymatic biofuel cells have been reported to last for 3 months, continuous operation was only observed over a period of 9 days [39]. This shortcoming is due to the loss of enzyme activity, thereby resulting in shorter device lifetime. On the other hand, biobatteries and abiotic fuel cells have been able to produce the most comparable electrical properties that may closely match lithium ion cells but have only shown to survive for a few weeks at most [28,31]. The cell described here was able to produce almost 10 times more power than recently reported abiotic fuel cells [40,41], around 5 times more power than enzymatic biofuel cells [31,42-45], 2 to 6 times more power than biobattery that uses a zinc phosphate anode [28,31] and has a 1.25 times more current density that of the traditional lithium ion cell $[46,47]$. 

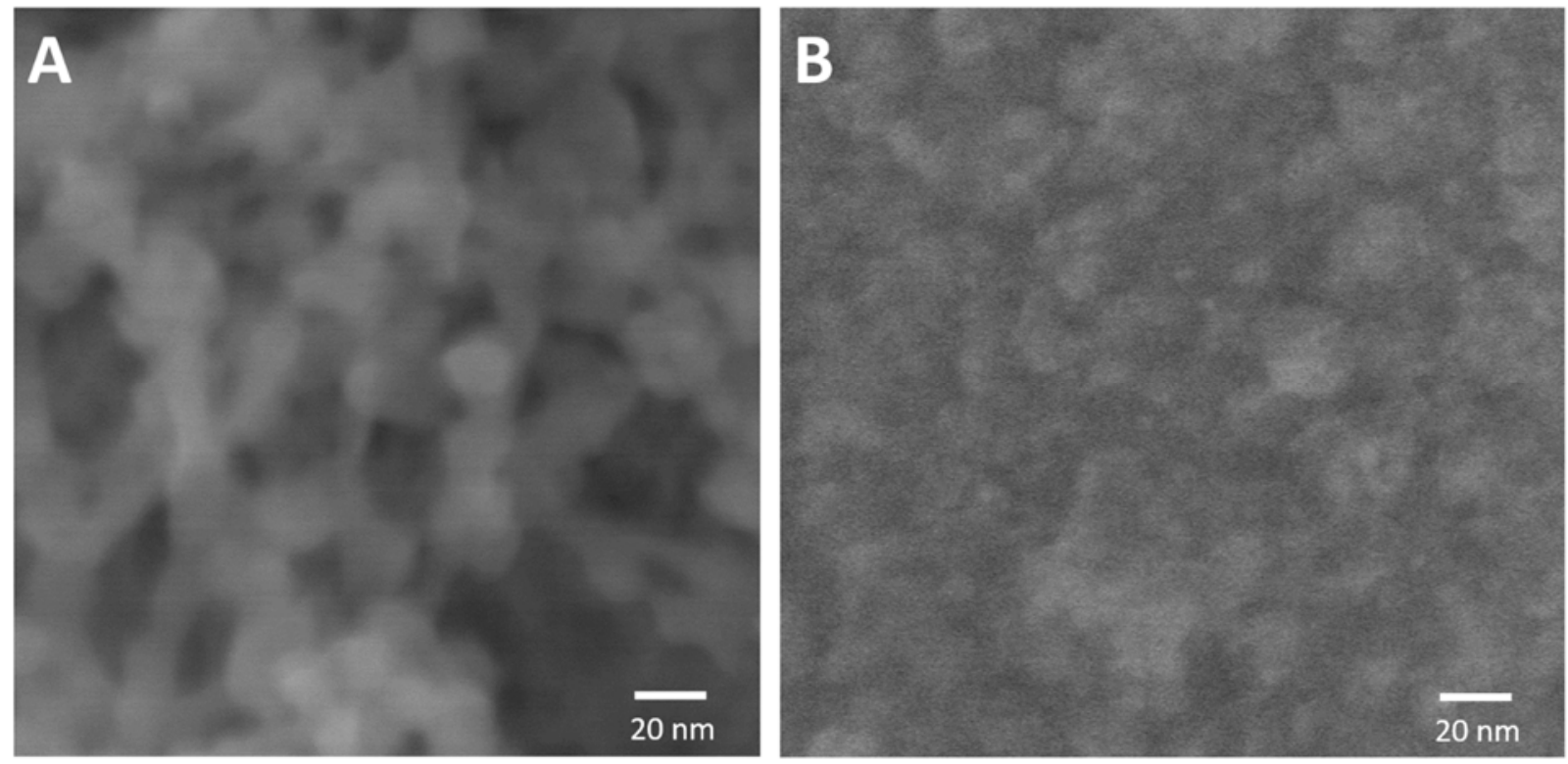

Figure 1. Scanning electron micrograph of $\mathrm{Al} / \mathrm{Au} / \mathrm{ZnO}$ anode (A) before and (B) after discharging in physiological saline $(\mathrm{pH} 7.4,20 \mathrm{mM}$ phosphate, $2.7 \mathrm{mM} \mathrm{KCl}$ and $137 \mathrm{mM}$ $\mathrm{NaCl}$ ) to form nonporous aluminum hydroxide and zinc phosphite lamellae layer on the anode.

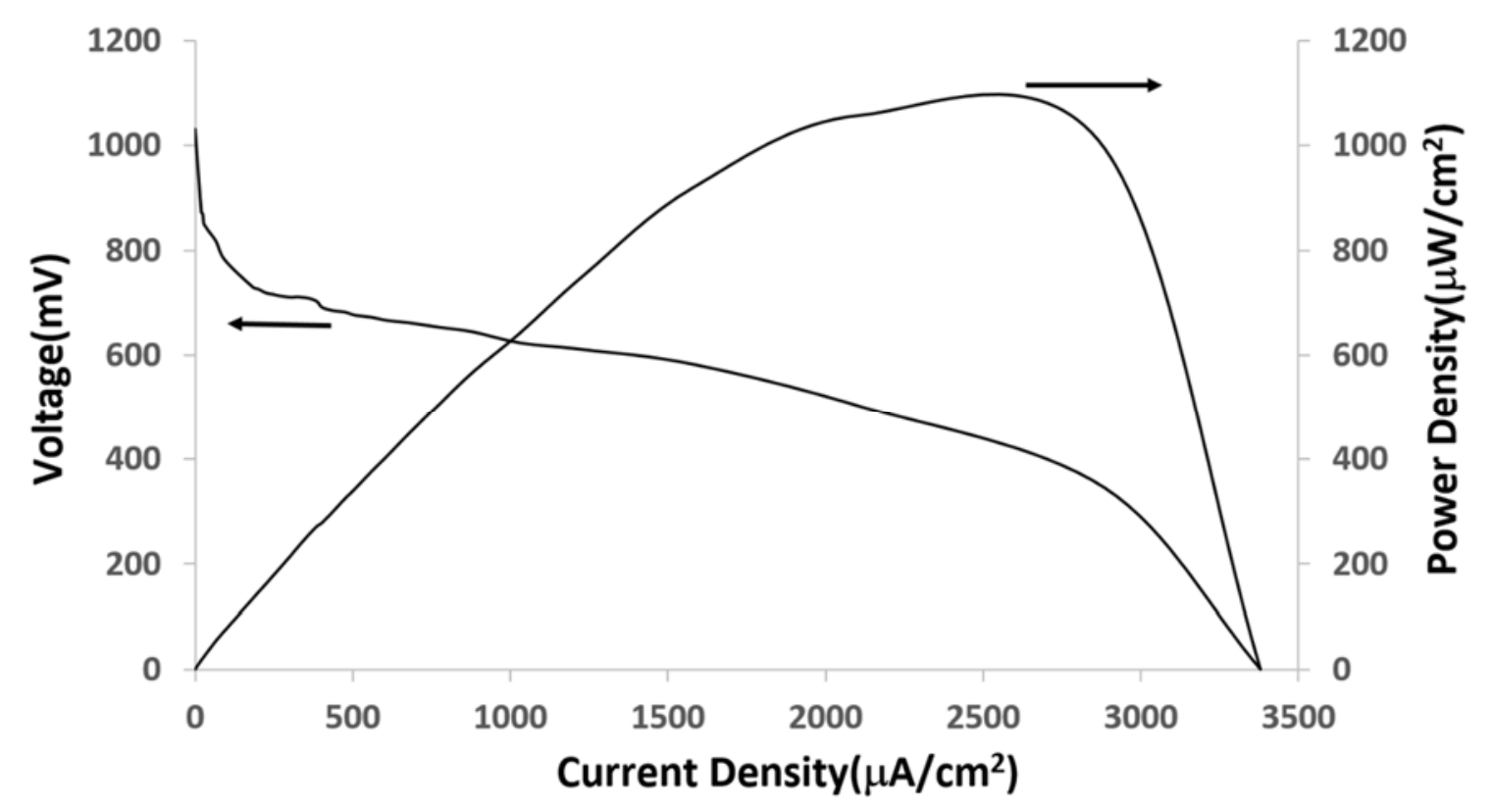

Figure 2. Current-voltage characterization and power impact curves of the hybrid cell in $\mathrm{O}_{2}$-saturated phosphate buffered saline.

The durability of the cells employing $\mathrm{Al} / \mathrm{Au} / \mathrm{ZnO}$ anodes and platinum cathodes were operated continuously under a $3 \mathrm{k} \Omega$ load in all three separate electrolyte environments are depicted in Figure 3. Polarization curves were obtained once a day for 55 days, with the electrolyte environment being exchanged with fresh electrolyte every two days. Overall, the results show good durability and stability of voltage and current density. Upon operating the cell in saline solution, significant deterioration of the anode was observed. The $\mathrm{Al} / \mathrm{Au} / \mathrm{ZnO}$ anode in this environment was immediately discolored, followed 
by the appearance of pits in week 4 . In week 6 , the anode was completely corroded, which led to the complete decomposition of the $\mathrm{Al} / \mathrm{Au} / \mathrm{ZnO}$ anode. In this saline environment, the $\mathrm{Cl}^{-}$ions deteriorate the oxide layer on the anode, resulting in a lack of corrosion protection of the $\mathrm{Al} / \mathrm{Au} / \mathrm{ZnO}$ anode. However, the current density of the cell operating in phosphate buffer dropped significantly after 10 days of continuous operation, whereas the cell operating in physiological saline rich solution maintained its stability over 40 days of operation. The addition of a halide salt such as $\mathrm{NaCl}$ may contribute to the formation of nonporous aluminum hydroxide and zinc phosphite lamellae layer [30] on the surface of the anode in physiological saline that provides corrosion protection of the $\mathrm{A} / \mathrm{Au} / \mathrm{ZnO}$ anode because the film acts as non-oxidizing anode inhibitors, thereby preventing galvanic corrosion of the anode and ionic current flow. The formation of the composite lamellae layer further inhibits power generation during long term durability testing.

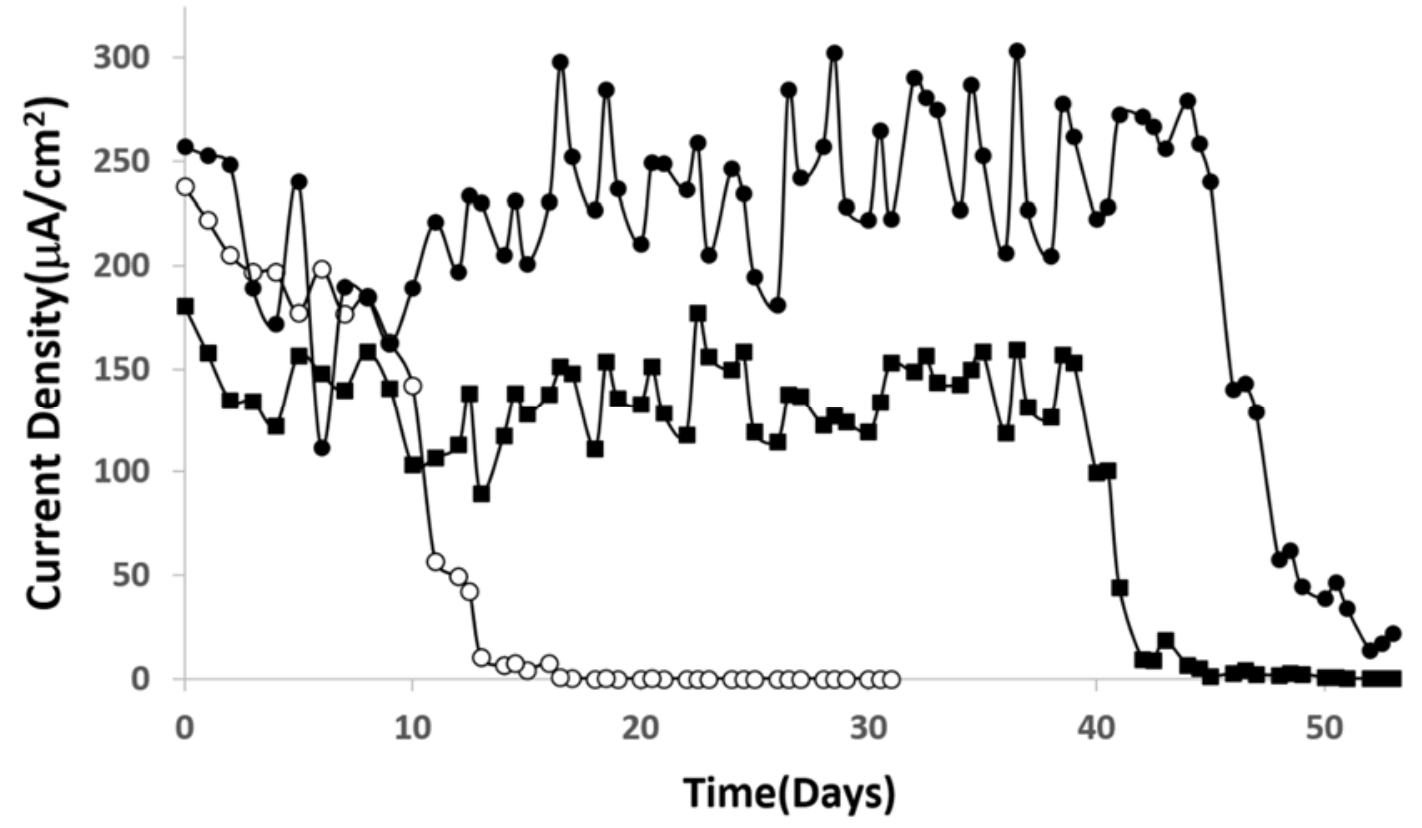

Figure 3. Stability curve of the hybrid cell continuously operating in $\mathrm{O}_{2}$-saturated $(\circ)$ phosphate buffer, $(\bullet)$ saline, and $(\bullet)$ physiological saline buffer environments.

Electrochemical impedance spectroscopy (EIS) was performed to evaluate the inhibitive properties of the corrosion protection composite films. Nyquist and Bode phase angle plots of $\mathrm{Al} / \mathrm{Au} / \mathrm{ZnO}$ anodes $(1 \mathrm{~cm} \times 0.5 \mathrm{~cm})$ treated in saline and physiological saline electrolyte environments for a period of 55 days are shown in Figures 4 and 5. The typical electrical equivalent circuit obtained for coated metal surfaces exposed to corrosive environments [48] agree with the electrical equivalent circuit for the $\mathrm{Al} / \mathrm{Au} / \mathrm{ZnO}$ anodes presented in Figure 6. Figure 6A represent the equivalent circuit model for $\mathrm{Al} / \mathrm{Au} / \mathrm{ZnO}$ metal/ electrolyte interface, where $R_{\Omega}$ is the solution resistance, $R_{p}$ is the polarization resistance, and $C_{p}$ is the coating capacitance. The equivalent circuit shown in Figure $6 \mathrm{~B}$, with the Warburg element $\left(\mathrm{Z}_{\mathrm{w}}\right)$, represents the $\mathrm{Al} / \mathrm{Au} / \mathrm{ZnO}$ anode coated with aluminum hydroxide and zinc phosphite composite film upon discharging in physiological saline, where $\mathrm{R}_{\mathrm{ct}}$ is the charge transfer resistance and $\mathrm{C}_{\mathrm{dl}}$ is the double layer capacitance. This anode exhibited very small high frequency capacitive loop and is nearly shielded by a diffusion tail in the low frequency domain, thereby showing Warburg behavior. The Nyquist and 
Bode plots for the coated anode are different from those of the saline treated anode. The high frequency capacitive loop in the Nyquist plot is evident in the saline treated $\mathrm{Al} / \mathrm{Au} / \mathrm{ZnO}$ anode. In the Bode plot, the maximum phase angle is found to be $67.1^{\circ}$ and is shifted towards the low frequency region. These results reveal the absence of a corrosion protective film on the saline treated anodic surface. One time constant was observed for the saline treated anode, which suggest that it could only influence the charge transfer process. The $|\mathrm{Z}|$ vs. f curves also shows a decrease in impedance values for the saline treated anode, which suggest the formation of conductive paths in the $\mathrm{ZnO}$ film is due to water uptake and the penetration of corrosive $\mathrm{Cl}^{-}$ions that deteriorates the $\mathrm{ZnO}$ layer and the anodic substrate.

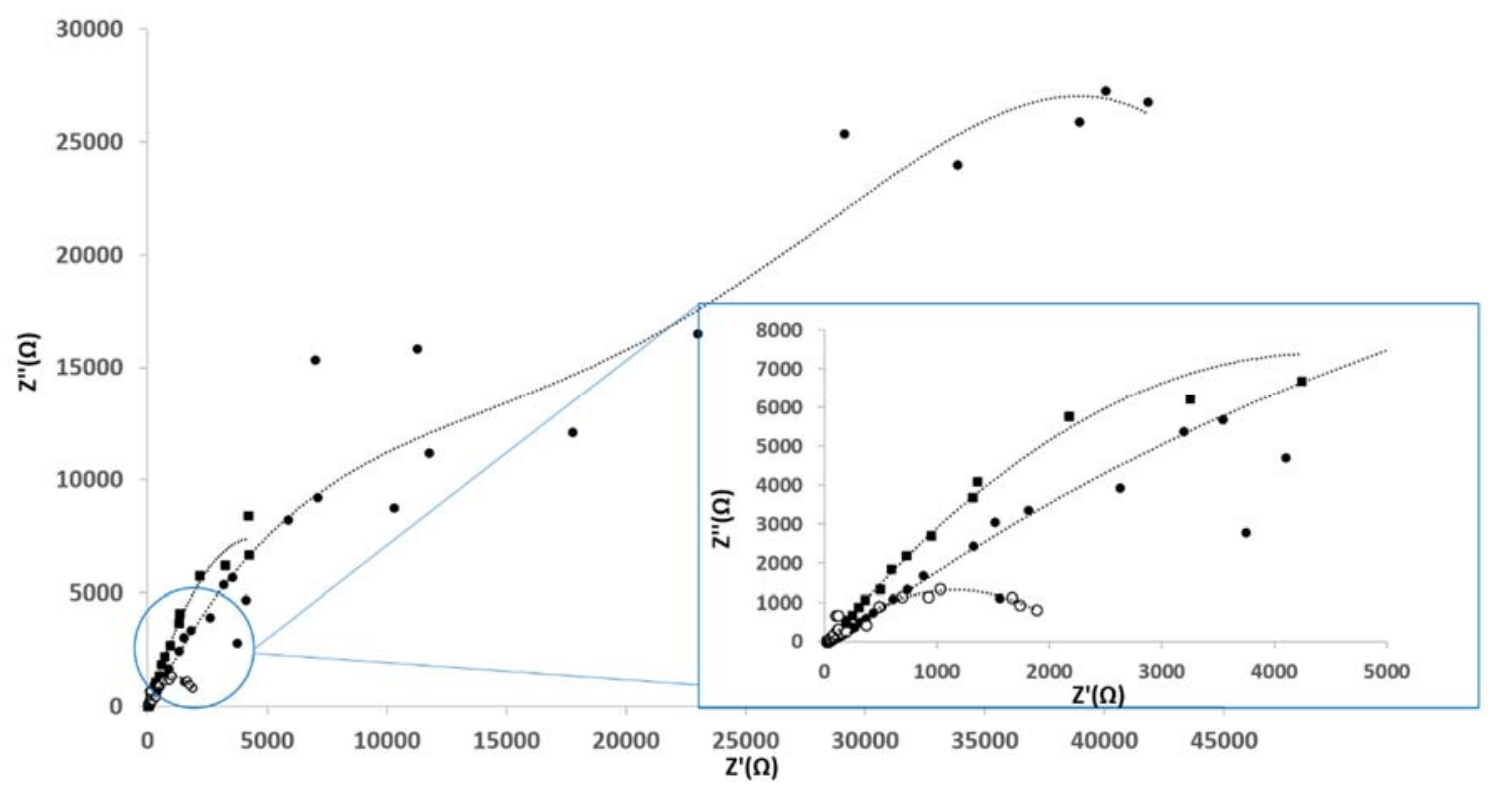

Figure 4. Nyquist plots of (०) untreated $\mathrm{Al} / \mathrm{Au} / \mathrm{ZnO}$, (-) saline treated $\mathrm{Al} / \mathrm{Au} / \mathrm{ZnO}$, and (•) $\mathrm{Al}(\mathrm{OH})_{3}$ and $\mathrm{ZnHPO}_{3}$ coated $\mathrm{Al} / \mathrm{Au} / \mathrm{ZnO}$ anodes.

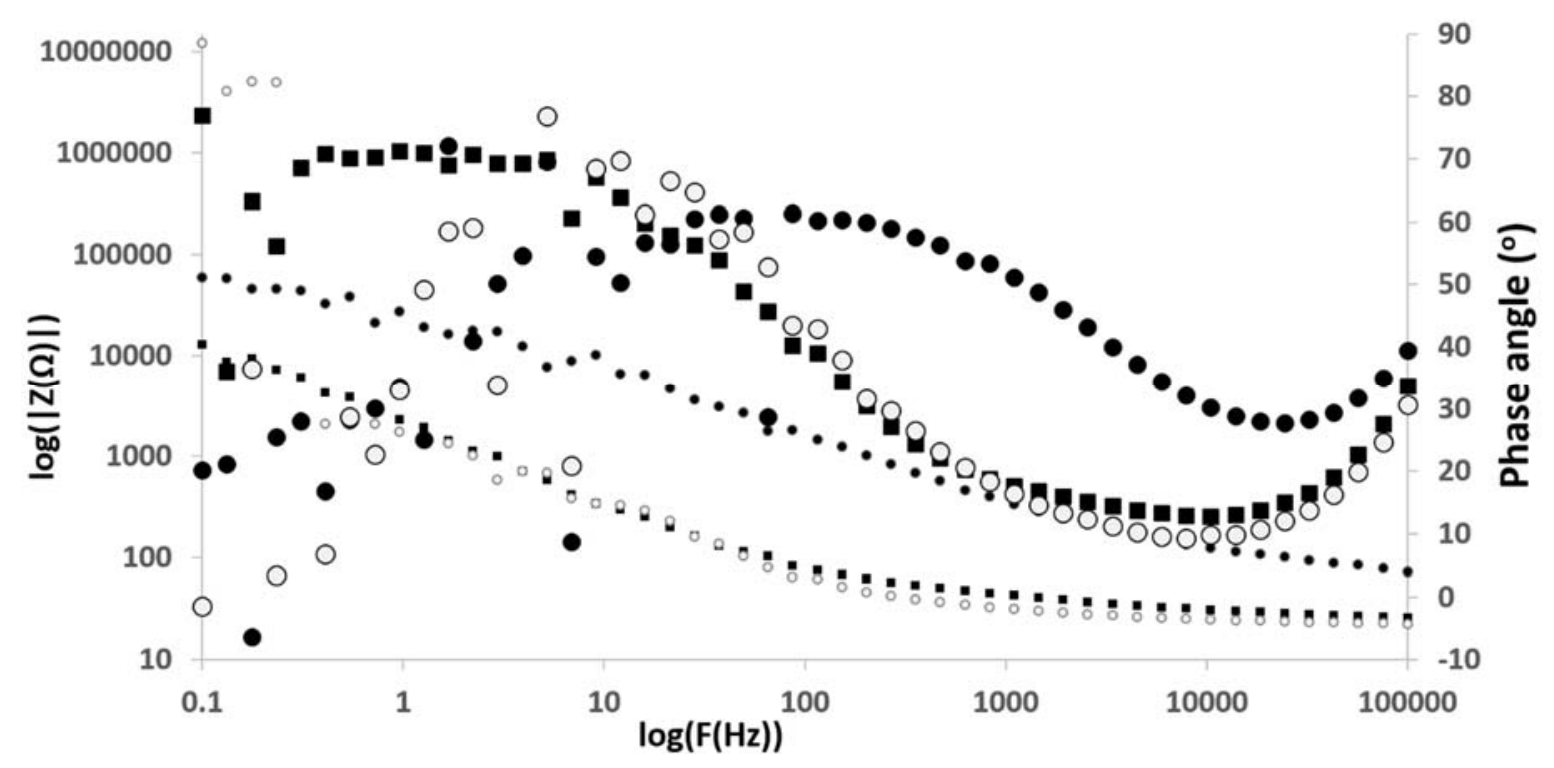

Figure 5. Impedance vs. Frequency plots and Bode phase plots for $(\circ)$ untreated $\mathrm{Al} / \mathrm{Au} / \mathrm{ZnO}$, (•) saline treated $\mathrm{Al} / \mathrm{Au} / \mathrm{ZnO}$, and $(\bullet) \mathrm{Al}(\mathrm{OH})_{3}$ and $\mathrm{ZnHPO}_{3}$ coated $\mathrm{Al} / \mathrm{Au} / \mathrm{ZnO}$ anodes. 


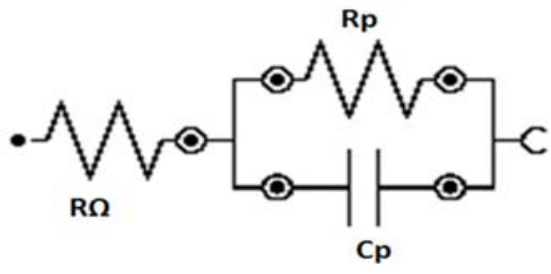

(A)

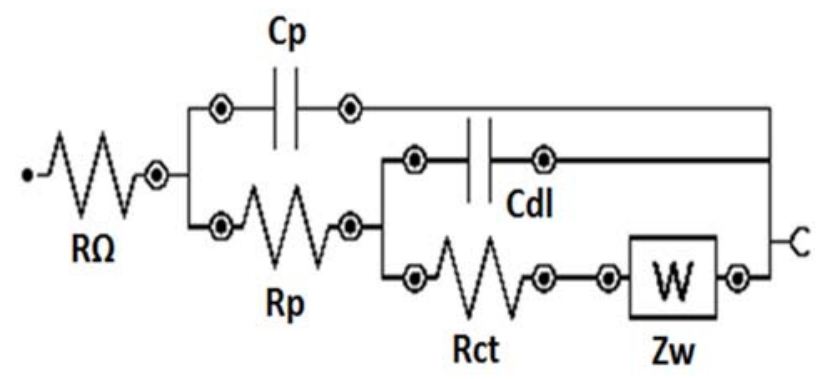

(B)

Figure 6. Equivalent electrical circuit utilized to model the impedance behavior of (A) saline treated $\mathrm{Al} / \mathrm{Au} / \mathrm{ZnO}$ and $(\mathbf{B}) \mathrm{Al}(\mathrm{OH})_{3}$ and $\mathrm{ZnHPO}_{3}$ coated $\mathrm{Al} / \mathrm{Au} / \mathrm{ZnO}$ anodes.

The aluminum hydroxide and zinc phosphite coated anode exhibited a Warburg behavior, which indicate the inhomogeneity of corrosion protection film on the anode surface. This film aids in the prevention of the diffusion of oxygen or $\mathrm{Cl}^{-}$ions to the $\mathrm{Al}$ substrate and thus inhibits the corrosion of the anode, while enabling the transport of $\mathrm{Zn}^{2+}$ in the $\mathrm{ZnO}$ conductivity layer. A larger partial semicircle is observed from high frequency to low frequency indicating that the charge transfer resistance is dominant in the corrosion process due to the presence of corrosion protection film on the anode. This is also supported by the Bode plots, in which the phase angle maximum is slightly decreased $\left(61^{\circ}\right)$ and shifted towards higher frequency region compared to the saline treated anode. At anode surfaces coated with aluminum hydroxide and zinc phosphite upon discharging physiological saline environment, the phase angle maximum shows two time constants. The maximum in the low frequency domain relates to the porous $\mathrm{ZnO}$ films on the $\mathrm{Al}$ surface and the second maximum in the higher frequency domain relates to the charge transfer resistance by the corrosion protection film. The $|Z| v s$. f curves shows an increase in impedance values, which infers that the protective surface film is a combination of zinc oxide film, aluminum hydroxide and zinc phosphite [15]. The formation of aluminum hydroxide and zinc phosphite on the $\mathrm{Al} / \mathrm{Au} / \mathrm{ZnO}$ anode results in a larger charge transfer resistance, $\mathrm{R}_{\mathrm{ct}}$, value $20.8 \mathrm{k} \Omega \mathrm{cm}^{2}$, whereas smaller values of 4.48 and $4.17 \mathrm{k} \Omega \mathrm{cm}^{2}$ was observed for the saline treated and the phosphate buffer treated anodes, respectively. The double layer capacitance, $\mathrm{C}_{\mathrm{dl}}$, value of $1.50 \mu \mathrm{F} \mathrm{cm} \mathrm{cm}^{-2}$ for the aluminum hydroxide and zinc phosphite coated anode is lower than that of 48.3 and $32.5 \mu \mathrm{F} \mathrm{cm}^{-2}$ observed for the saline treated and phosphate buffer treated anodes, respectively. An admittance of the constant phase element of the double layer was only observed for the aluminum hydroxide and zinc phosphite coated anode, which can be attributed to the formation of a densely packed dielectric film or an increase of the double layer thickness. The high $\mathrm{R}_{\mathrm{ct}}$ and lower $\mathrm{C}_{\mathrm{dl}}$ values of the composite film on $\mathrm{Al} / \mathrm{Au} / \mathrm{ZnO}$ anode discharged in physiological saline reveal the dense protective film formation on the surface of $\mathrm{Al} / \mathrm{Au} / \mathrm{ZnO}$ anode.

In addition, the $\mathrm{Al} / \mathrm{Au} / \mathrm{ZnO}$ anodes were examined after the 55 days discharge in saline, phosphate buffer and physiological saline environments. The polarization behavior of the $\mathrm{Al} / \mathrm{Au} / \mathrm{ZnO}$ anodes are depicted in Figure 7. The bare $\mathrm{Al} / \mathrm{Au}$ anode shows higher anodic activity than that of the bare $\mathrm{Al}$ anode, suggesting the $\mathrm{Al} / \mathrm{Au}$ is more inert than the bare $\mathrm{Al}$. The corrosion potential ( $\mathrm{E}_{\text {corr }}$ ) and corrosion current density ( $i_{\text {corr }}$ ) can be determined using the Tafel extrapolation method [49] and are approximated with the position of the anodic current in the polarization curves. The activation of $\mathrm{Al}$ via nano- $\mathrm{ZnO}$ seeds deposited on the surface of $\mathrm{Al} / \mathrm{Au}$ anode allow for zinc ions to react with phosphite groups to form 
aluminum hydroxide and zinc phosphite composite in phosphate buffer and physiological saline buffer [15]. The $\mathrm{Al} / \mathrm{Au} / \mathrm{ZnO}$ anode coated with this protective film shifts the potential of the anode to become more anodic and thus decreases corrosion current and enhances the electrical properties. This shift toward more anodic values allows for an increased deposition of the corrosion protection film [50], which further suggests an increased corrosion resistance. The protective efficiency $P(\%)$ of the $\mathrm{Al} / \mathrm{Au} / \mathrm{ZnO}$ anode coated with aluminum hydroxide and zinc phosphite composite film was determined by [51]:

$$
P(\%)=100\left(1-\frac{K_{f}}{K_{f}^{0}}\right)
$$

where $K_{f}$ and $K_{f}^{0}$ are the faradaic conductances in the presence and absence of the composite film, respectively. Here the protective efficiency of $98.5 \%$ was calculated for the $\mathrm{Al} / \mathrm{Au} / \mathrm{ZnO}$ anode coated with aluminum hydroxide and zinc phosphite composite film. The polarization behavior of the $\mathrm{Al} / \mathrm{Au} / \mathrm{ZnO}$ anode coated with this protective film demonstrates the effective corrosion protection of the anode.

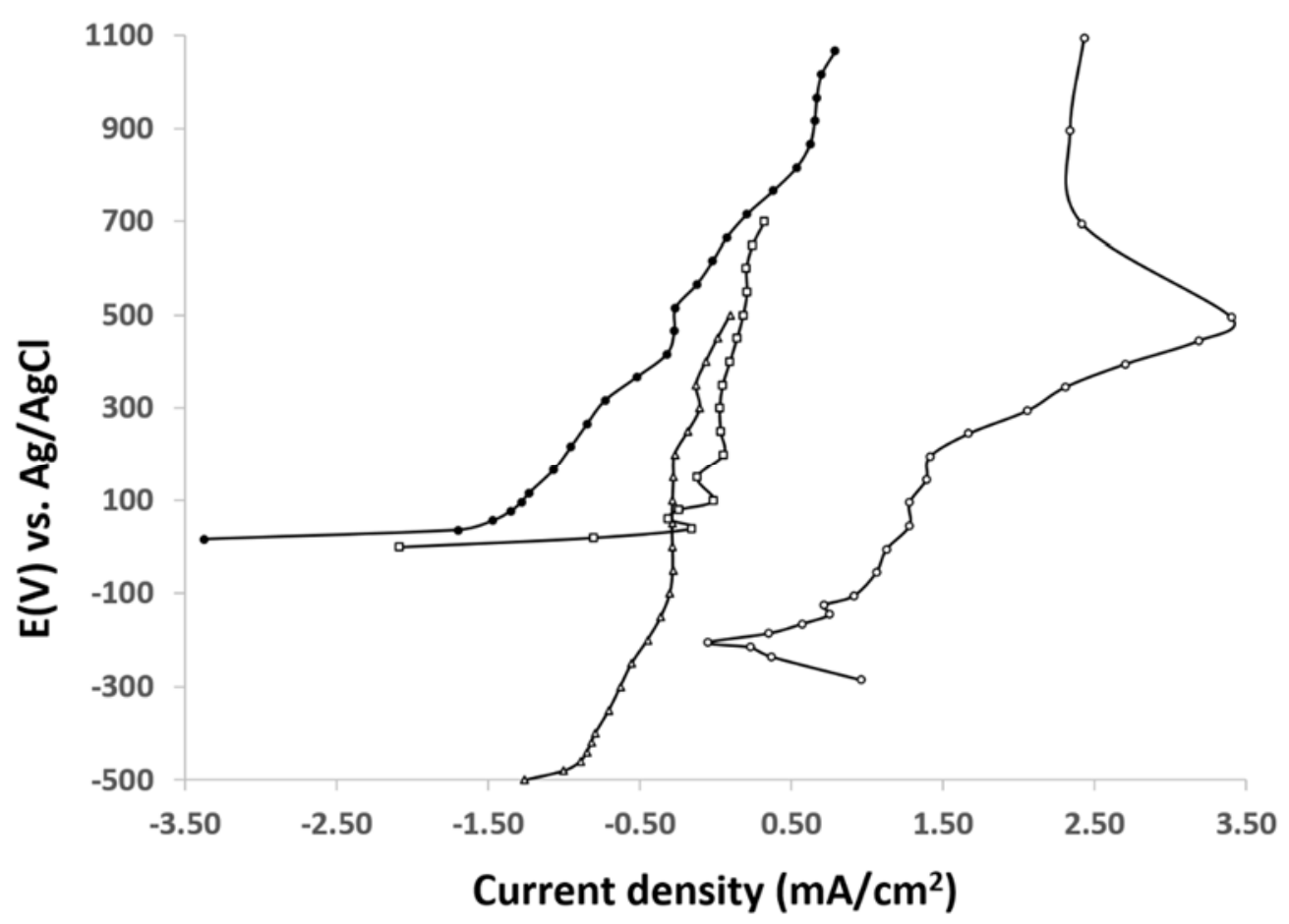

Figure 7. Polarization curves for $(\Delta)$ bare $\mathrm{Al},(\square)$ bare $\mathrm{Al} / \mathrm{Au},(\circ)$ untreated $\mathrm{Al} / \mathrm{Au} / \mathrm{ZnO}$, and (•) $\mathrm{Al}(\mathrm{OH})_{3}$ and $\mathrm{ZnHPO}_{3}$ coated $\mathrm{Al} / \mathrm{Au} / \mathrm{ZnO}$ anodes.

The aluminum hydroxide and zinc phosphite composite films are impermeable to $\mathrm{O}_{2}$ and thus prevent corrosion [28,30] even in the presence of $\mathrm{NaCl}$ for over one month and allow for increased cell performance. Therefore, the cell operating in physiological saline buffer resulted in the most durable cell, lasting up to 50 days. The observed life span of the $\mathrm{Al} / \mathrm{Au} / \mathrm{ZnO}$ anode in physiological saline is much longer that previously reported abiotic fuel cells [28-30]. The enhanced durability of the cell operating in physiological saline buffer suggests that localized sites of aluminum hydroxide and zinc phosphite composite film enable the development of micro regions on the surface of the anode to allow $\mathrm{Zn}^{2+}$ ions to react with phosphites to form corrosion protection film while reducing the galvanic 
current [52]. Thereby, resulting in an improved corrosion resistance when operating in physiological saline buffer.

\section{Conclusion}

The corrosion protection of the as-fabricated $\mathrm{Al} / \mathrm{Au} / \mathrm{ZnO}$ anode was characterized in saline, phosphate rich buffer and physiological saline buffer. The $\mathrm{Al} / \mathrm{Au} / \mathrm{ZnO}$ anode discharged in phosphate rich buffer and physiological saline buffer showed protection against corrosion via the formation of aluminum hydroxide and zinc phosphite films. The resulting corrosion resistant anode led to improved electrical properties (current density) and extended life span of the hybrid fuel cell when compared to abiotic fuel cells based on similar anodes. The use of the sol-gel dip coating process yielded a much larger surface area of zinc oxide, which was employed to activate the aluminum anode. The biomimetic approach employed in this work is more economical and environmentally safe compared to other techniques that require harmful nitrates, nitrites, acidic baths and high energy equipment. Here, we demonstrate a novel approach to providing corrosion resistant films on $\mathrm{Al} / \mathrm{Au} / \mathrm{ZnO}$ anodes while harvesting energy. The cell exhibited an enhanced performance and extended lifetime over other abiotic fuel cells. The excellent performance of the cell can be attributed to the combined effect of the cathode and the $\mathrm{Al} / \mathrm{Au} / \mathrm{ZnO}$ anode that operated in physiological saline buffer to achieve an open circuit voltage of $1.03 \mathrm{~V}$. The $\mathrm{Al} / \mathrm{Au} / \mathrm{ZnO}$ has significant potential for developing long lasting hybrid cells.

\section{Acknowledgment}

This work was supported by the National Science Foundation (Award ECCS-\#1349603).

\section{Author Contributions}

Gymama Slaughter conceived and designed this study. Brian Stevens carried out the experiments and was supervised by Gymama Slaughter. All authors discussed the results, interpreted the data, wrote the manuscript and approved the manuscript.

\section{Conflicts of Interest}

The authors declare no conflict of interest.

\section{References}

1. Jiang, G.; Zhou, D. Technology advances and challenges in hermetic packaging for implantable medical devices. In Implantable Neural Prostheses 2; Springer: New York, NY, USA, 2010; pp. 27-61.

2. Yun, Y.; Dong, Z.; Lee, N.; Liu, Y.; Xue, D.; Guo, X.; Kuhlmann, J.; Doepke, A.; Halsall, B.; Heineman, W.; et al. Revolutionizing biodegradable metals. Mater. Today 2009, 12, 22-32.

3. Samani, M.; Mahnam, A.; Hosseini, N. An Arbitrary Waveform Wearable Neuro-stimulator System for Neurophysiology Research on Freely Behaving Animals. J. Med. Signals Sens. 2014, $4,94-102$. 
4. Bennet, D.; Kim, S. Implantable microdevice for peripheral nerve regeneration: materials and fabrications. J. Mater. Sci. 2011, 46, 4723-4740.

5. Okamoto, E.; Inoue, T.; Watanabe, K.; Hashimoto, T.; Iwazawa, E.; Abe, Y.; Chinzei, T.; Isoyama, T.; Kobayashi, S.; Saito, I.; et al. Development of an Implantable High-Energy and Compact Battery System for Artificial Heart. Artif. Organs 2003, 27, 184-188.

6. DeRosa, J.F.; Beard, R.; Carim, H.; Dubin, S. Polarization and Corrosion Studies of Porous and Solid Anodes for Implantable Power-Generating Electrodes. IEEE Trans. Biomed. Eng. 1973, 5, 345-349.

7. Wilson, D.; Herweg, B. New Technology for Implantable Cardioverter Defibrillators. Card. Electrophysiol. Clin. 2014, 6, 261-267.

8. Chanlen, T.; Hongeng, S.; Nasongkla, N. Tri-component copolymer rods as an implantable reservoir drug delivery system for constant and controllable drug release rate. J. Polym. Res. 2012, $19,1-12$.

9. Gensler, H.; Sheybani, R.; Li, P.; Mann, R.; Meng, E. An implantable MEMS micropump system for drug delivery in small animals. Biomed. Microdevices 2012, 14, 483-496.

10. Juanola-Feliu, E.; Miribel-Català, P.; Páez Avilés, C.; Colomer-Farrarons, J.; González-Piñero, M.; Samitier, J. Design of a customized multipurpose nano-enabled implantable system for in vivo theranostics. Sensors 2014, 14, 19275-19306.

11. Novak, M.T.; Yuan, F.; Reichert, W.M. Macrophage embedded fibrin gels: An in vitro platform for assessing inflammation effects on implantable glucose sensors. Biomaterials 2014, 35, 9563-9572.

12. Vaddiraju, S.; Legassey, A.; Qiang, L.; Wang, Y.; Burgess, D.; Papadimitrakopoulos, F. Enhancing the Sensitivity of Needle-Implantable Electrochemical Glucose Sensors via Surface Rebuilding. J. Diabetes Sci. Technol. 2013, 7, 441-451.

13. Morais, R.; Frias, C.; Silva, N.; Azevedo, J.; Serôdio, C.; Silva, P.; Ferreira, J.; Simões, J.; Reis, M. An activation circuit for battery-powered biomedical implantable systems. Sens. Actuators A Phys. 2009, 156, 229-236.

14. Slaughter, G.; Sunday, J. A membraneless single compartment abiotic glucose fuel cell. J. Power Sources 2014, 261, 332-336.

15. Slaughter, G.; Sunday, J.; Stevens, B. Energy conversion from aluminium and phosphate rich solution via $\mathrm{ZnO}$ activation of aluminium. Mater. Chem. Phys. 2015, 163, 245-252.

16. Williams, D. The Williams Dictionary of Biomaterials; Liverpool University Press: Liverpool, UK, 1999.

17. Williams, D. On the nature of biomaterials. Biomaterials 2009, 30, 5897-5909.

18. Slaughter, G. Improving the Biocompatibility of Implantable Bioelectronics Devices. In Implantable Bioelectronics; Katz, E., Ed.; Wiley-VCH Verlag GmbH \& Co. KGaA: Weinheim, Germany, 2014; pp. 265-283.

19. Anderson, J. Biological responses to materials. Annu. Rev. Mater. Res. 2001, 31, 81-110.

20. Nail-plates, F. Corrosion of orthopaedic implants. J. Bone Jt. Surg. 1959, 41B, 810-820.

21. Williams, D. Tissue-biomaterial interactions. J. Mater. Sci. 1987, 22, 3421-3445.

22. Aksakal, B.; Yildirim, Ö.S.; Gul, H. Metallurgical failure analysis of various implant materials used in orthopedic applications. J. Fail. Anal. Prev. 2004, 4, 17-23. 
23. Reclaru, L.; Lerf, R.; Eschler, P.-Y.; Meyer, J.-M. Corrosion behavior of a welded stainless-steel orthopedic implant. Biomaterials 2001, 22, 269-279.

24. Drago, D.; Bettella, M.; Bolognin, S.; Cendron, L.; Scancar, J.; Milacic, R.; Ricchelli, F. Potential pathogenic role of $\beta$-amyloid 1-42-aluminum complex in Alzheimer's disease. Int. J. Biochem. Cell Biol. 2008, 40, 731-746.

25. Yao, F.; Zhang, R.; Tian, H.; Li, X. Studies on the interactions of Copper and Zinc ions with $\beta$-Amyloid peptides by a surface plasmon resonance biosensor. Int. J. Mol. Sci. 2012, 13, 11832-11843.

26. United States Environmental Protection Agency (USEPA). Nitrates and Nitrites: TEACH Chemical Summary; USEPA: Washington, DC, USA, 2007.

27. Kouisni, L.; Azzi, M.; Zertoubi, M.; Dalard, F.; Maximovitch, S. Phosphate coatings on magnesium alloy AM60 part 1: Study of the formation and the growth of zinc phosphate films. Surf. Coat. Technol. 2004, 185, 58-67.

28. Shin, W.; Lee, J.; Kim, Y.; Steinfink, H.; Heller, A. Ionic Conduction in $\mathrm{Zn}_{3}\left(\mathrm{PO}_{4}\right)_{2} \cdot 4 \mathrm{H}_{2} \mathrm{O}$ Enables Efficient Discharge of the Zinc Anode in Serum. J. Am. Chem. Soc. 2005, 127, 14590-14591.

29. Shin, W.; Lee, J.; Lee, J.; Park, Y.; Heller, A. Zinc Anode Operating in Physiological Condition. In Proceedings of the 215th The Electrochemical Society (ECS) Meeting, San Francisco, CA, USA, 24-29 May 2009; Abstract \#242, pp. 242-242.

30. Heller, A. Potentially implantable miniature batteries. Anal. Bioanal. Chem. 2006, 385, 469-473.

31. Stolarczyk, K.; Kizling, M.; Majdecka, D.; Żelechowska, K.; Biernat, J.; Rogalski, J.; Bilewicz, R. Biobatteries and biofuel cells with biphenylated carbon nanotubes. J. Power Sources 2014, 249, 263-269.

32. Skunik-Nuckowska, M.; Grzejszczyk, K.; Stolarczyk, K.; Bilewicz, R.; Kulesza, P. Integration of supercapacitors with enzymatic biobatteries toward more effective pulse-powered use in small-scale energy harvesting devices. J. Appl. Electrochem. 2014, 44, 497-507.

33. Nguyen, T.; Waterman, J.; Staiger, M.; Woodfield, T. Controlling in vitro corrosion rate of pure $\mathrm{Mg}$ with rough surface texture via biomimetic coating systems. Corros. Eng. Sci. Technol. 2012, 47, 358-364.

34. Waterman, J.; Birbilis, N.; Dias, G.J.; Woodfield, T.B.F.; Staiger, M.P. Improving in vitro corrosion resistance of biomimetic calcium phosphate coatings for $\mathrm{Mg}$ substrates using calcium hydroxide layer. Corros. Eng. Sci. Technol. 2012, 47, 340-345.

35. Xia, W.; Lindahl, C.; Engqvist, H.; Lausmaa, J. Biomimetic hydroxyapatite deposition on titanium oxide surfaces for biomedical application. In Advances in Biomimetics; INTECH Open Access Publisher: Rijeka, Croatia, 2011.

36. Raoufi, D.; Raoufi, T. The effect of heat treatment on the physical properties of sol-gel derived ZnO thin films. Appl. Surf. Sci. 2009, 255, 5812-5817.

37. Barton, S.C. Handbook of Fuel Cells: Advances in Electrocatalysis, Materials, Diagnostics and Durability; John Wiley \& Sons: Hoboken, NJ, USA, 2009.

38. Minteer, S.; Liaw, B.; Cooney, M. Enzyme-based biofuel cells. Curr. Opin. Biotechnol. 2007, 18, $228-234$. 
39. Zebda, A.; Cosnier, S.; Alcaraz, J.; Holzinger, M.; Le Goff, A.; Gondran, C.; Bouche, F. Single glucose biofuel cells implanted in rats power electronic devices. Sci. Rep. 2013, 3, doi:10.1038/srep01516.

40. Hussein, L.; Urban, G. An Abiotically Catalyzed Glucose Fuel Cell Based on Decorated Buckypaper. In Proceedings of the 14th International Conference on Miniaturized Systems for Chemistry and Life Sciences, Groningen, The Netherlands, 3-7 October 2010.

41. Oncescu, V.; Erickson, D. A microfabricated low cost enzyme-free glucose fuel cell for powering low-power implantable devices. J. Power Sources 2011, 196, 9169-9175.

42. Halámková, L.; Halámek, J.; Bocharova, V.; Szczupak, A.; Alfonta, L.; Katz, E. Implanted biofuel cell operating in a living snail. J. Am. Chem. Soc. 2012, 134, 5040-5043.

43. Szczupak, A.; Halámek, J.; Halámková, L.; Bocharova, V.; Alfonta, L.; Katz, E. Living battery-Biofuel cells operating in vivo in clams. Energy Environ. Sci. 2012, 5, 8891-8895.

44. MacVittie, K.; Halámek, J.; Halámková, L.; Southcott, M.; Jemison, W.; Lobel, R.; Katz, E. From "cyborg" lobsters to a pacemaker powered by implantable biofuel cells. Energy Environ. Sci. 2013, 6, 81-86.

45. Cinquin, P.; Gondran, C.; Giroud, F.; Mazabrard, S.; Pellissier, A.; Boucher, F.; Alcaraz, J.-P. A glucose biofuel cell implanted in rats. PLoS One 2010, 5, e10476.

46. Dahn, J.; Jiang, J.; Mushurchak, L.; Buhrmester, C.; Wang, R. The drugstore Li-ion cell. Electrochem. Soc. Interface 2005, 14, 27-31.

47. Dahn, J.; Jiang, J.; Moshurchak, L.; Fleischauer, M.; Buhrmester, C.; Krause, L. High-rate overcharge protection of LiFePO4-based Li-ion cells using the redox shuttle additive 2, 5-ditertbutyl-1, 4-dimethoxybenzene. J. Electrochem. Soc. 2005, 152, A1283-A1289.

48. Chen, X-B.; Zhou, X.; Abbott, T.; Easton, M.; Birbilis, N. Double-layered manganese phosphate conversion coating on magnesium alloy AZ91D: Insights into coating formation, growth and corrosion resistance. Surf. Coat. Technol. 2013, 217, 147-155.

49. Jegannathan, S.; Narayanan, T.S.N.; Ravichandran, N.; Rajeswari, S. Performance of zinc phosphate coatings obtained by cathodic electrochemical treatment in accelerated corrosion tests. Electrochim. Acta 2005, 51, 247-256.

50. Jegannathan, S.; Narayanan, T.S.N.; Ravichandran, N.; Rajeswari, S. Formation of zinc phosphate coating by anodic electrochemical treatment. Surf. Coat. Technol. 2006, 200, 6014-6021.

51. Tsuji, N.; Nozawa, K.; Aramaki. K. Ultrathin protective films prepared by modification of an N,N-dimethylalkylamine monolayer with chlorosilanes for preventing corrosion of iron. Corros. Sci. 2000, 42, 1523-1538.

52. Li, G.Y.; Lian, J.S.; Niu, L.Y.; Jiang, Z.H.; Jiang, Q. Growth of zinc phosphate coatings on AZ91D magnesium alloy. Surf. Coat. Technol. 2006, 201, 1814-1820.

(C) 2015 by the authors; licensee MDPI, Basel, Switzerland. This article is an open access article distributed under the terms and conditions of the Creative Commons Attribution license (http://creativecommons.org/licenses/by/4.0/). 